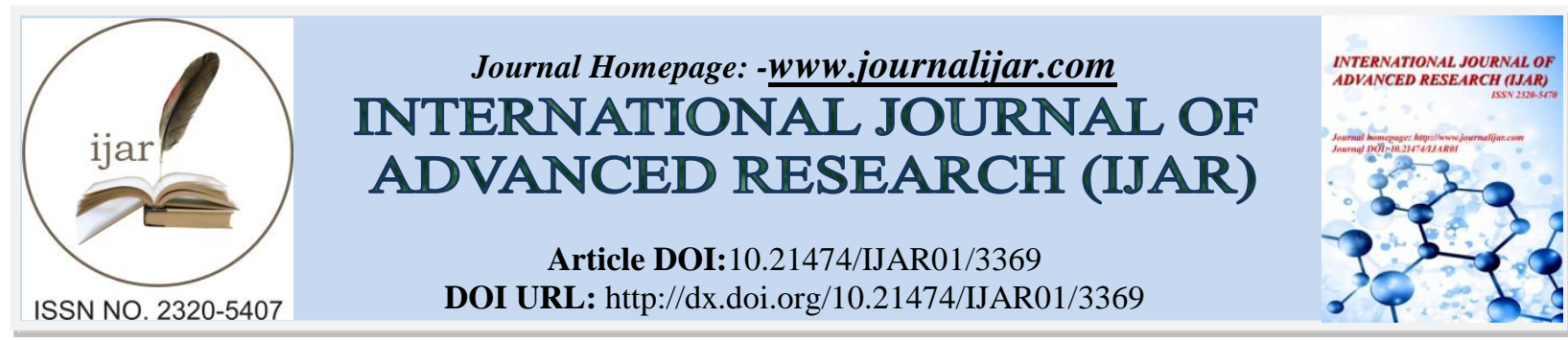

RESEARCH ARTICLE

\title{
PORTFOLIO PERFORMANCE ANALYSIS WITH JENSEN'S METHOD ON CAPM AND APT MODELS
}

\author{
Dr. Andi Desfiandi ${ }^{1}$, Ita Fionita, $\mathrm{MM}^{1}$ and Prof. Dr. Hapzi Ali CMA ${ }^{2}$. \\ 1. Institute of Informatics \& Business Darmajaya, Bandar Lampung Indonesia. \\ 2. Postgraduate of MercuBuana University, Jakarta Indonesia.
}

\section{Manuscript Info}

Manuscript History

Received: 22 December 2016

Final Accepted: 16 January 2017

Published: February 2017

Key words:-

Capital Asset Model Pricing (CAPM), Arbitrage pricing Theory (APT), Index Jensen's

\begin{abstract}
The purpose of this research is to analyze the portfolio using CAPM and APT models to predict stock returns LQ 45 in BEI. The issues raised in this study were: 1) Which combination of companies that produce optimal portfolio using the CAPM model; 2) Which company combination that produces an optimal portfolio by using the APT model; 3) How is the comparison of optimal portfolio by using Jensen's Index on the model of CAPM and APT models. Beta in this study using simple linear regression analysis method to the CAPM model and multiple linear regression model for APT. The independent variables in this model is LQ 45, while the dependent variable is the market risk premium, exchange rate, SBI, inflation and GDP. To determine the optimal portfolio return is analyzed using a model CAPM and APT models, whereas for portfolio performance measure used Jensen's index. On the other hand to know the difference between the CAPM model with the APT model used t test. The sample used in this study as many as 31 companies are determined by the criteria 1). Companies listed in the LQ 45 in BEI. 2). The company is listed in the LQ 45 actively traded 2 consecutive years from January 2010 to December 2011. The results of this study indicate that there are significant differences between Jensen's Index on the model of CAPM and APT models. With Jensen's Index score APT model larger than the CAPM model.
\end{abstract}

Copy Right, IJAR, 2017,. All rights reserved.

\section{Introduction:-}

In the stock market almost all investment contain elements of uncertainty or risk. Investors do not know with certainty the results to be obtained from its investments. In such circumstances it is said that these investors face risks in its investments. Given this risk, the investor will suffer or benefit that is not as expected, resulting in the emergence of irregularities, divergence is often called the uncertainty (uncertainty). In theory it is said that a portfolio of high risk will provide high returns as well (high risk, high return), so the greater the risk will be greater the return that would be acceptable, and vice versa. But not all investors agree with the statement, and the main desire of investors is to minimize risk and increase the cost (minimize risk and maximize return). So that they will look for a portfolio that has the lowest possible risk to the optimum return.

Corresponding Author:-Dr. Andi Desfiandi.

Address:-Institute of Informatics \& Business Darmajaya, Bandar Lampung Indonesia. 
Model balance (analysis tools) will help the understanding of how to determine the relevant risk of an asset, as well as the relationship of risk and expected return on an asset when the market is in equilibrium. Two kinds of balance popular models that can be used in predicting exchange for shares (return) is expected is the Capital Asset Pricing Model (CAPM) and the Arbitrage Pricing Theory (APT). Both models are popular because of the ease of application as well as the assumptions underlying these two models.

Markowitz's portfolio theory put forward in 1952 (Arzac and Bawa, 1977), known as the Markowitz model, it provides a way how to invest efficiently and optimally. By forming the optimal portfolio. The purpose of forming the optimal portfolio is to fulfill the principles of investing. "Obtaining yield (return) at the desired level with minimum risk". To minimize the risk, there should be diversification in investing, is to establish a portfolio or to invest funds not only in one asset alone but to several asset. The problem is how large a proportion of the funds must be invested in each asset in order to obtain the desired level of yield with minimum risk. Bring Arzac research and use two parameters CAPM by behavioral approach safety- first on the return and risk, which found that safety-first approach implies a cautious attitude towards risk, portfolio choice and balance of the market comparable to that implied by the approach of expected utility. Black (1974) suggests that the estimator for the portfolio only the Rt $\mathrm{R}$. It is exactly the same as tests used for capital asset pricing model, using the world market portfolio to calculate this is consistent with the notion that taxes are what cause the world capital asset pricing model does not continue smoothly.

CAPM (Capital Asset Pricing Model) is a theory that tries to explain how an asset is determined by the market price, or how to determine the level of profit that is deemed worthy of an investment. Sharpe (1964) analyze how the links between return an asset $\left(\mathrm{R}_{\mathrm{i}}\right)$ with the market portfolio return $\left(\mathrm{R}_{\mathrm{m}}\right)$ is. By making a simple regression equation in which the dependent variable his return an asset and its independent variable return of the market portfolio will be determined how or the relationship between the return of the market portfolio with the return of certain assets. Cornell Research (1979), was able to show that the CAPM can be used to detect the investor excel in the world of asymmetric information, but they do not arouse demonstration CAPM as a practical tool for measuring performance.

APT (Arbitrage Pricing Theory) is an alternative model of CAPM to assess the financial asset. The financial model developed by Ross (1976) have emerged based on the idea that the financial markets are competitive, the arbitrage will make two assets that share similar characteristics, such as equally (riskless) or without taking the risk of giving expectations of return of the same. APT basically uses the idea also that two investment opportunities that have the same identical characteristics can not be sold at different prices (the law of one price). When assets are sold with the same characteristics different prices there will be a chance to do arbitrage, buying valuable assets cheap and sell at a higher price at the same time so as to obtain profit without risk.

APT model emphasizes that the level of expected return (expected return) is heavily influenced by macro-economic factors and not by the unique risks. We can assume that there are factors in arbitrage pricing as specific portfolios tend to be affected by the influence of joint (common influence). If the expected risk premium of each portfolio will be proportionate to the market beta portfolio, the APT and CAPM will give the same result.. Based on the description above, where it is known that the CAPM and APT models have strengths and weaknesses of each to determine which rewards portfolio shares (return) the most optimal and profitable for investors. The authors are interested to analyze the portfolio by using both models to compare measurement models that can be known where the most optimal as an asset assessment tool that can assist investors in selecting a portfolio decision making. In the APT model of macro-economic factors used in this study is inflation, gross domestic product, interest rates and the exchange rate against the US dollar (exchange rate).

The author's intent in doing this Research are:-

1. Determine the combination of companies which produce optimal portfolio using the CAPM model.

2. Knowing which combination of companies that produce optimal portfolio by using the APT model.

3. Determine the optimal portfolio performance comparison using Jensen's Index on the model of CAPM and APT models.

\section{Literature Review:-}

\section{Capital Asset Pricing Model:-}

Capital Asset Pricing Model (CAPM) is a model for determining the price of an asset (Sharpe, 1964). This model bases itself on equilibrium. Mathematically CAPM formula is as follows : $E(R i)=R f+(R m-R f) \beta i$ 


\section{Arbitrage Pricing Theory:-}

Approach Arbitrage Pricing Theory (APT) states that the expected return on an asset is a linear function of various macro-economic factors and the sensitivity of changes in any factor beta coefficient expressed by each of these factors (Ross, 1976). APT is the equations : $\mathrm{E}(\mathrm{Ri})-\mathrm{E}(\mathrm{R} 0)=\lambda 1 \beta \mathrm{i} 1+\ldots+\lambda \mathrm{k} \beta \mathrm{ik}$

\section{Index Jensen's:-}

Index Jensen's is also known as unique return expressed as alpha $(\alpha)$. If alpha $=0$ means no unique return, if the alpha has a positive value, the fund's investment performance was better than the market index (ZalmiZubir, 2011: 259).

Jensen's measure:

Alpha $=$ average return-expected return

\section{Methods:-}

The method used in the preparation of this research is descriptive and associative, ie data obtained are collected, processed, and analyzed mainly for the SBI interest rate, the rupiah against the US dollar, inflation, GDP, the risk premium market and the stock price on the company -the company listed as LQ45 shares in the Indonesian stock Exchange. This research was conducted using documentary data of Indonesia Stock Exchange period January 2010 to December 2011 (historical research or documentary research).

The population used in this study is LQ 45 listed in the Indonesia Stock Exchange. While the sample is determined by using purposive sampling method, which is intended to achieve certain limits or goals expected from this research. For that set of samples with the following criteria: The company whose shares including the shares are actively traded on an ongoing basis and is LQ 45 in Indonesia Stock Exchange 2010-2011 period.

\section{This study uses multiple methods of data collection are as follows:-}

1. Research Library (Library Research)

2. Research literature that research done by studying the literature related to the issues discussed authors in this study.

3. Field Research (Field Research) Field research is research conducted directly on the object of research, in order to get the data in relation in the field of research. This data collection can be done by means of observation and documentation.

\section{Data Analysis Techniques:-}

The analysis tool that authors use the quantitative analysis. Quantitative analysis is the analysis used by using the calculation of the figures, by comparing the value of E (R) CAPM model and the value of E (R) APT model, then do different test on the index Jensen's $(\alpha)$ CAPM model with index Jensen's $(\alpha)$ APT model using T-Test Paired Samples Test (Output Program SPSS version 17:00). Technical analysis of the data in this study through several stages, among others:

\section{Model CAPM:-}

1. Determining the estimation period (estimation period) that will be used in research. This study period from January 2010 until December 2011.

2. Calculate the real return (Ri) on shares in companies LQ 45 by the formula:

$$
\mathrm{R}_{\mathrm{it}}=\frac{P_{i t}-P_{i t-1}}{P_{i t-1}}
$$

3. Calculate market return $(\mathrm{Rm})$ is the return obtained from the ratio of stock index LQ 45 actively traded by the formula:

$$
\mathrm{R}_{\mathrm{mt}}=\frac{L Q 45_{t}-L Q 45_{t-1}}{L Q_{t-1}}
$$

4. Determining the regression model to find $\beta$ shares of each company by the equation: $R m-R f=X$ and $R i-R f=$ Y. 
5. After $\beta$ shares of each company is known, then calculated the expected return of each company and created a line of SML. The formula used is:

$$
\mathrm{E}(\mathrm{R})=\Delta \mathrm{Rf}+(\Delta \mathrm{Rm}-\Delta \mathrm{Rf}) \beta \mathrm{i}
$$

6. Determine the combination of portfolio based on shares of companies whose line is above the SML.

7. Determine the portfolio return ( $\mathrm{Rp})$ any combination of the portfolio by the formula:

$$
\mathrm{Rp}=\frac{R i 1}{\Sigma \mathrm{Ri} \mathrm{KP}} \times \mathrm{Ri} 1+\frac{R i 2}{\Sigma \mathrm{Ri} \mathrm{KP}} \times \mathrm{Ri} 2+\ldots+\frac{\mathrm{Ri} \mathrm{n}}{\Sigma \mathrm{Ri} \mathrm{KP}} \times \mathrm{Ri} \mathrm{n}
$$

8. Determining the regression model to search for any combination of $\beta$ stock portfolio CAPM model with the equation:

$$
\begin{gathered}
\mathrm{Rm}-\mathrm{Rf}=\mathrm{X} \\
\mathrm{Rp} 1-\mathrm{Rf}=\mathrm{Y} 1, \mathrm{Rp} 2-\mathrm{Rf}=\mathrm{Y} 2 \ldots . . \mathrm{Rpn}-\mathrm{Rf}=\mathrm{Yn}
\end{gathered}
$$

After $\beta$ shares of each company is known, then the expected return is calculated every combination of portfolio CAPM model with the following formula:

$$
E(R)=R f+(R m-R f) \beta i
$$

\section{Model APT:-}

1. Determining the estimation period (estimation period) that will be used in research. This study period from January 2010 until December 2011.

2. Calculate the real return (Ri) on shares in companies LQ 45 by the formula:

$$
\mathrm{R}_{\mathrm{it}}=\frac{P_{i t}-P_{i t-1}}{P_{i t-1}}
$$

3. Calculate market return $(\mathrm{Rm})$ is the return obtained from the ratio of stock index LQ 45 actively traded by the formula:

$$
\mathrm{R}_{\mathrm{mt}}=\frac{L Q 45_{t}-L Q 45_{t-1}}{L Q_{t-1}}
$$

4. Determining the regression model to find $\beta$ shares of each company by the equation $: R m-R f=X$ danRi $-\mathrm{Rf}=$ Y.

5. e. After $\beta$ shares of each company is known, then calculated the expected return of each company and created a line of SML. The formula used is:

$$
\mathrm{E}(\mathrm{R})=\Delta \mathrm{Rf}+(\Delta \mathrm{Rm}-\Delta \mathrm{Rf}) \beta \mathrm{i}
$$

6. Determine the combination of portfolio based on shares of companies whose line is above the SML.

7. Determine the portfolio return (Rp) any combination of the portfolio by the formula : $\mathrm{Rp}=\frac{R i 1}{\Sigma \mathrm{Ri} K \mathrm{KP}} \times \mathrm{Ri} 1+$ $\frac{R i 2}{\Sigma R i K P} \times \operatorname{Ri} 2+\ldots+\frac{\operatorname{Rin}}{\Sigma R i K P} \times \operatorname{Rin}$

8. h. Determining the regression model to search for any combination of $\beta$ stock portfolio APT model by the equation:

$$
\begin{gathered}
\mathrm{Rm}-\mathrm{Rf}=\mathrm{X} 1, \mathrm{I}-\mathrm{Rf}=\mathrm{X} 2, \mathrm{Kurs}-\mathrm{Rf}=\mathrm{X} 3, \mathrm{PDB}-\mathrm{Rf}=\mathrm{X} 4 \mathrm{dan} \\
\mathrm{Rp} 1-\mathrm{Rf}=\mathrm{Y} 1, \mathrm{Rp} 2-\mathrm{Rf}=\mathrm{Y} 2 \ldots . . \mathrm{Rpn}-\mathrm{Rf}=\mathrm{Yn}
\end{gathered}
$$

9. After $\beta$ shares of each company is known, then calculated the expected return any combination of APT model portfolio with the following formula:

$$
\mathrm{E}(\mathrm{Rp})=\mathrm{RF}+(\mathrm{Rm}-\mathrm{Rf}) \beta \mathrm{i}+(\mathrm{I}-\mathrm{Rf}) \beta \mathrm{i}+(\text { Kurs-Rf }) \beta \mathrm{i}+(\mathrm{PDB}-\mathrm{Rf}) \beta \mathrm{i}
$$




\section{Index Jensen's:-}

2. Calculating the index Jensen's model portfolio CAPM and APT model by using the following formula

$$
: \alpha=\mathrm{Ri}-\mathrm{E}(\mathrm{R})
$$

3. Calculating the average (average) from the calculation of Jensen's index $(\alpha)$ model of CAPM and APT model, then the calculation results be ranked from the largest to the smallest.

4. Regression Jensen's Index value $(\alpha)$ on the CAPM and APT models with T-Test Paired Samples Test to compare the significance between $\alpha$ CAPM model with the APT model.

\section{Result and Discussion:-}

An Overview of Research Object

LQ-45 Index is an index composed of 45 stocks with liquidity (liquid) is the highest, which are selected by multiple selection criteria. In addition to an assessment of liquidity, the selection of these stocks also considers market capitalization. LQ-45 index was first launched on February 24, 1997. Today the basis for the calculation is July 13, 1994 with a base value of 100. All issuers listed on the Stock Exchange are classified into nine industry sectors according to the classification established BEI, named JASICA (Jakarta Industrial Classification). Nine (9) sectors contained in the incoming BEI LQ-45 index in 2010 and 2011 that were in line SML and is ranked top 3 in each sector according to its capitalization, among others:

\section{Agriculture sector:-}

\section{PT. Astra Agro Lestari Tbk.}

PT. Astra Agro Lestari Tbk (the "Company") was established on October 3, 1988 under the name. Suryaraya horizon, based on Deed 12 Notary RukmasantiHardjasatya, SH, in the company's articles of association, the scope of activities of the company is engaged in the plantation sector, trade, manufacturing, transportation, consulting and services.

PT. Perusahaan Perkebunan London Sumatra Tbk.

PT. Perusahaan Perkebunan London Tbk. (Company ") was established by Act No. 93 Notary RadenKadiman on December 18, 1962, and amended by Act No. 20 dated September 9, 1963. The Company is engaged in the plantation located in Sumatra, Java, Kalimantan and Sulawesi with the main product of crude palm oil and rubber, and a small amount of cocoa, tea and seeds.

\section{Property and Real Estate Sector:-}

PT. LippoKarawaciTbk.

PT. KarawaciTbk is single Reksakencana based on Deed 223 Notary MisahardiMilawarta SH, on October 15,1990 in Jakarta. The Company is engaged in the field of urban development, development of large-scale integrated, malls, healthcare, restaurants, infrastructure and property, and portfolio management.

\section{Mining sector:-}

PT. Adaro Energy Tbk.

PT. Adaro Energy Tbk. (Formerly PT. Padang Karunia) was established by Act No. 25 on July 28, 2004 before Notary SukawatySumadi, SH, in Jakarta. In accordance with article 3 of the articles of association of companies engaged in trade, services, industry, transportation of coal, workshop activities, mining and construction.

PT. Indo TambangrayaTbk.

PT. Indo TambangrayaTbk. (The "Company") was established by Act No. 13 Notary Benny Kristianto, SH, on September 12, 1987, and approved by the Ministry of Justice of the Republic of Indonesia in Decree No. C2 640.HT.01.01.TH'89 dated January 20, 1989. The main activity of the company is mining, with investment in subsidiaries, and marketing services to the related companies.

PT. International Nickel Indonesia Tbk.

PT. International Nickel Indonesia Tbk., Was established on July 25, 1968 by Deed No. 49 compiled by Eliza Pondaag, a Notary in Jakarta. The main holding company is Vale S.A., a company registered in Brazil. The company's main activity is the exploration and mining, processing, storage, transportation and marketing of nickel and associated mineral products. 


\begin{abstract}
Basic and Chemical Industry Sector:-
PT. Holcim Indonesia Tbk.

PT. Holcim Indonesia Tbk. ( "Limited") was established within the framework of the Foreign Capital Investment Law No. 1, 1967, as amended by Law No. 111970 based on Deed 53 dated June 15, 1971 before Notary Abdul Latief, SH, and from 1 January 2006 the company changed the name of PT. Semen Cibinong Tbk. into PT. Holcim Indonesia Tbk. The scope of this company is engaged in the operation of a cement plant and associated activities in the cement industry and to invest in other companies.
\end{abstract}

\title{
Miscellaneous Industry Sector:-
}

PT. Astra International Tbk.

PT. Astra International Tbk. (The "Company") was established in 1957 as PT. Astra International Incorporated, and in 1990 the company changed its name to PT. Astra International Tbk. Headquartered in Sunter, Jakarta. The scope of activities of companies engaged in general trade, industrial, mining, transportation, agriculture, construction, consulting and services.

\section{Trade in Services and Investment sector:-}

PT. United Tractors Tbk.

United Tractors ( "UT" or "Limited") was established on October 13, 1972, as a heavy equipment distributor in Indonesia. The company went public and listed its shares on the Jakarta Stock Exchange on 19 September 1989. In addition to being a distributor of heavy equipment in Indonesia, UT also plays an active role in the field of coal mining and coal mining business.

\section{Financial sector:-}

PT. Bank Central Asia Tbk.

PT. Bank Central Asia Tbk. ( "Bank") was founded with the name of the Company NV Commerce and Industrie Semarang Knitting Factory on October 10, 1955. The name has been changed for some time, the latest changes on May 21, 1974, namely PT. Bank Central Asia in front of the Notary RidwanSuselo. The head office of PT. BCA is located in Jakarta and two branch offices in Singapore and Hong Kong.

PT. Bank MandiriTbk.

The Indonesian government set up the Bank (the "Bank") on October 2, 1998, as part of the bank restructuring program in Indonesia. In July 1999, four (4) other banks, Bank BumiDaya, Bank Dagang Negara, Export-Import Bank Indonesia and Bank Pembangunan Indonesia joined Bank Mandiri.

PT. Bank Rakyat Indonesia Tbk.

PT. Bank Rakyat Indonesia Tbk. ("Limited") was formally established by the Act. No. 21 in 1968, but the roots of its history can be traced back since 1895. BRI went public in November 2003, and now the government has $56.8 \%$ of the shares issued and the remainder is owned by the public. BRI is famous for its focus on financing, Micro and Small and Medium Enterprises (SMEs).

\section{Sector Industrial Goods and Consumption:-}

PT. Unilever Indonesia Tbk.

PT. Unilever Indonesia Tbk. (The "Company") was established on December 5, 1933 with Lever Zeepfabrieken N.V name based on Deed 23 by Notary AH. Van Ophuijsen in Batavia. The company name was changed to PT. Unilever Indonesia by Deed No. 171 dated July 22, 1980 by notary KartiniMuljadi, SH, and then on June 30, 1997 based on Deed 92 company changed its name to PT. Unilever Indonesia Tbk., A notarized MudofirHadi, SH, in Jakarta. The Company is engaged in manufacturing, marketing, and distribution of consumer.

PT. Indofood SuksesMakmurTbk.

PT. Indofood SuksesMakmurTbk. (The "Company") was established on August 14, 1990 under the name. PanganjayaIntikusuma based on Deed 228 Notary Benny Kristianto, SH, in Jakarta. PT. Indofood SuksesMakmurTbk., Operates in all stages of food manufacturing from the production of raw materials, processing, to distribution of the retailer to the consumer. 
PT. Kalbe FarmaTbk.

PT. Kalbe FarmaTbk. (The "Company") was established within the framework of Law on Domestic Investment No. 6 of 1968 and Act No. 12 in 1970, based on Deed 03 dated September 10, 1966 in presence of Notary Raden Imam SoesetyoPrawirokoesoemo in Jakarta. The company's main activity is the production, development and distribution of pharmaceutical products (human and veterinary).

\section{Infrastructure Sector, Utilities and Transportation:-}

PT. JasaMargaTbk.

PT. JasaMargaTbk. (The "Company") was established based on Government Regulation No. 041978 on the Establishment of Investment and State-Owned Company (Persero) in the field of management, maintenance and development of toll roads.

PT. Indika Energy Tbk.

PT. Indika Energy Tbk. (Formerly PT. IndikaIntiEnergi) was established by Act No. 31 dated October 19, 2000 before the Notary HasanalYani Ali Amin, A.H., in Jakarta. The scope of activities of the company are in the field of trade, construction, transportation, mining and services.

\section{Results of Testing Requirements Analysis Data:-}

Optimal portfolio

Outline Security Market Line (SML) describe the overall market return to longs systematic risk (the risk can not be diversified away) or Beta. With these criteria results obtained from the company's stock 229 sector, then pursed again with a selection system that shares a big 3 ratings (sectors) based on market capitalization. That was selected 17 stocks of companies included in the criteria for the establishment of an optimal portfolio as shown in the figure below:

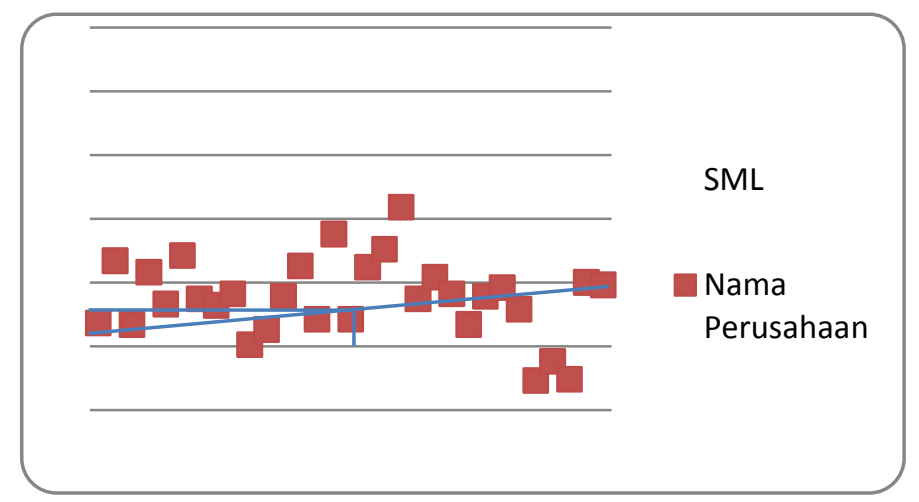

Figure 1:- Outline Security Market Shares LQ line 45 2010-2011

Figure 1 above shows the Security Market line is a line that shows the relationship between risk $(\beta)$ with the rate of profit. Where the upright axis is E (Ri) (expected return) and the flat axis illustrates the beta ( $\beta$ ) of each company. SML line drawn from a point $\mathrm{Rf}$ (risk free) cutting line $\mathrm{Rm}$ (market return) at $\beta=1$. There are 9 industrial sector with 31 stocks of companies from all sectors of the incoming LQ 45 period of 2010 and 2011. In the image can be viewed from 31 LQ 45 after made the Security Market line then that position is above the line SML there are only 22 stocks. And the selection is again entering the top 3 rankings by market capitalization per sector then acquired 17 shares of nine sectors. 
Table 1:- Stocks are selected for a combination of optimal portfolio

\begin{tabular}{|c|c|c|c|c|}
\hline No & Code & Name & Sector & Symbol \\
\hline 1 & AALI & Astra Agro Lestari Tbk. & 1 & $\mathrm{~A}$ \\
\hline 2 & LSIP & PP London Sumatera Tbk. & 1 & $\mathrm{~B}$ \\
\hline 3 & LPKR & LIPPOKarawaciTbk. & 2 & $\mathrm{C}$ \\
\hline 4 & ADRO & Adaro Energy Tbk. & 3 & $\mathrm{D}$ \\
\hline 5 & ITMG & Indo TambangrayaMegahTbk. & 3 & $\mathrm{E}$ \\
\hline 6 & INCO & International Nickel Indonesia Tbk. & 3 & $\mathrm{~F}$ \\
\hline 7 & SMCB & Holcim Indonesia Tbk. & 4 & $\mathrm{G}$ \\
\hline 8 & ASII & Astra International Tbk. & 5 & $\mathrm{H}$ \\
\hline 9 & UNTR & United Tractors Tbk. & 6 & $\mathrm{I}$ \\
\hline 10 & BBCA & Bank Central Asia Tbk. & 7 & $\mathrm{~J}$ \\
\hline 11 & BMRI & Bank MandiriTbk. & 7 & $\mathrm{~K}$ \\
\hline 12 & BBRI & Bank Republik Indonesia Tbk & 7 & $\mathrm{~L}$ \\
\hline 13 & UNVR & Unilever Indonesia Tbk. & 8 & M \\
\hline 14 & INDF & Indofood SuksesMakmurTbk. & 8 & $\mathrm{~N}$ \\
\hline 15 & KLBF & Kalbe FarmaTbk. & 8 & $\mathrm{O}$ \\
\hline 16 & JSMR & JasaMargaTbk. & 9 & $\mathrm{P}$ \\
\hline 17 & INDY & Indika Energy Tbk. & 9 & Q \\
\hline \multicolumn{3}{|c|}{ Information: } & & \\
\hline \multicolumn{3}{|c|}{ Sector $1=$ Agriculture } & & \\
\hline \multicolumn{3}{|c|}{ Sector $2=$ Property and Real Estate } & & \\
\hline \multicolumn{3}{|c|}{ Sector 3 = Mining Sector } & & \\
\hline \multicolumn{3}{|c|}{ Sector 4 = Basic and Chemical Industry } & & \\
\hline \multicolumn{3}{|c|}{ Sector $5=$ Various Industries } & & \\
\hline \multicolumn{3}{|c|}{ Sector $6=$ Trade in Services and Investment } & & \\
\hline \multicolumn{3}{|c|}{ Sector 7 = Financial Sector } & & \\
\hline \multicolumn{3}{|c|}{ Sector $8=$ Industrial Goods and Consumption } & & \\
\hline \multicolumn{3}{|c|}{ Sector $9=$ Infrastructure, Utilities and Transportation } & & \\
\hline
\end{tabular}

In this study to determine the combined portfolio writer used a tree diagram that is a way to describe the nature of a hierarchical structure in graphical form. Tree (tree diagram) a specific type of diagram that has a network topology (relationship) is unique (AdhiDarmawanSutjiadi, 2003). Each stock companies get the opportunity, and equal opportunities to represent the sector in the combined portfolio, resulting from the 17 stocks incorporated in 9 sectors industry produces 108 combined portfolio as shown in the following table. 
Table 2:- The combination of company shares

\begin{tabular}{|c|c|c|c|c|c|c|c|}
\hline No & Combination & No & Combination & No & Combination & No & Combination \\
\hline 1 & $\mathrm{C}, \mathrm{D}, \mathrm{G}, \mathrm{H}$, & 8 & $\mathrm{C}, \mathrm{D}, \mathrm{G}, \mathrm{F}$ & 55 & $\mathrm{~B}, \mathrm{C}, \mathrm{D}, \mathrm{G}, \mathrm{H}$ & 82 & $\mathrm{~B}, \mathrm{C}, \mathrm{D}, \mathrm{G}$, \\
\hline 2 & C, E, G, & 9 & C.E.G. & 56 & $\mathrm{C}, \mathrm{E}, \mathrm{G}$ & 83 & $\mathrm{~B}, \mathrm{C}, \mathrm{E}, \mathrm{C}$ \\
\hline 3 & $\mathrm{C}, \mathrm{F}, \mathrm{G}$, & 30 & A, C, F & 57 & $\mathrm{~B}, \mathrm{C}, \mathrm{F}, \mathrm{G}, \mathrm{H}$ & 84 & M, Q \\
\hline 4 & $\mathrm{C}, \mathrm{D}, \mathrm{G}, \mathrm{H}, \mathrm{I}, \mathrm{K}, \mathrm{M}, \mathrm{P}$ & 31 & & 58 & & 85 & $\mathrm{~B}, \mathrm{C}, \mathrm{D}, \mathrm{G}, \mathrm{H}, \mathrm{I}, \mathrm{K}, \mathrm{M}, \mathrm{P}$ \\
\hline 5 & $\mathrm{C}, \mathrm{E}$, & 32 & $\mathrm{~A}, \mathrm{C}, \mathrm{E}, \mathrm{G}, \mathrm{H}, \mathrm{I}, \mathrm{K}, \mathrm{M}, \mathrm{Q}$ & 59 & $|\mathrm{~B}, \mathrm{C}, \mathrm{E}, \mathrm{G}, \mathrm{H}, \mathrm{I}, \mathrm{K}, \mathrm{M}, \mathrm{P}|$ & 86 & $\mathrm{~B}, \mathrm{C}, \mathrm{E}, \mathrm{G}$, \\
\hline 6 & $P$ & 33 & $Q$ & 60 & $\mathrm{P}$ & 87 & \\
\hline 7 & $\mathrm{M}, \mathrm{P}$ & 34 & A, C, D, G & 61 & $1, P$ & 88 & \\
\hline 8 & A, C, E, G, & 35 & A, C, E, G, & 62 & $B, C, B$ & 89 & $\mathrm{~B}, \mathrm{C}, \mathrm{I}$ \\
\hline 9 & & 36 & & 63 & & 90 & \\
\hline 10 & C, D & 37 & Q & 64 & $B, C$ & 91 & $B, C$ \\
\hline 11 & $C, E$, & 38 & A, C, E & 65 & $B, C$, & 92 & \\
\hline 12 & & 39 & & 66 & & 93 & \\
\hline 13 & C, D, G, & 40 & A, C, D, G, & 67 & $B, C$, & 94 & $B, C$, \\
\hline 14 & $C, E, G$ & 41 & A, C, E, G, & 68 & $B, C$, & 95 & $B, C$ \\
\hline 15 & & 42 & & 69 & & 96 & \\
\hline 16 & $\mathrm{C}, \mathrm{D}, \mathrm{G}$, & 43 & A, C, D, G, & 70 & $\mathrm{~B}, \mathrm{C}$, & 97 & $B, C$ \\
\hline 17 & & 44 & & 71 & & 98 & \\
\hline 18 & $P$ & 45 & A, C, F, & 72 & & 99 & \\
\hline 19 & $0, P$ & 46 & A, C, D, G, H, I & 73 & $B, C, D, C$ & 100 & B, C, D, G, \\
\hline 20 & & 47 & & 74 & $B, C, E$ & 101 & \\
\hline 21 & $0, \mathrm{P}$ & 48 & & 75 & $\mathrm{~B}, \mathrm{C}, \mathrm{F}, \mathrm{G}, \mathrm{H}$, & 102 & $\mathrm{~B}, \mathrm{C}, \mathrm{F}, \mathrm{G}$ \\
\hline 22 & C, D, G & 49 & A, C, D, G, H & 76 & $B, C$, & 103 & $\mathrm{~B}, \mathrm{C}, \mathrm{D}, \mathrm{C}$ \\
\hline 23 & & 50 & A, C, E, G, H, I, & 77 & & 104 & $O, Q$ \\
\hline 24 & & 51 & $\mathrm{~A}, \mathrm{C}, \mathrm{F}, \mathrm{G}, \mathrm{H}, \mathrm{I}, \mathrm{K}, \mathrm{O}, \mathrm{Q}$ & 78 & $\mathrm{~B}, \mathrm{C}, \mathrm{F}, \mathrm{G}, \mathrm{H}, \mathrm{I}, \mathrm{K}, \mathrm{O}, \mathrm{P}$ & 105 & $\mathrm{~B}, \mathrm{C}, \mathrm{F}, \mathrm{G}, \mathrm{H}$, \\
\hline 25 & & 52 & & 79 & $B, C, D, G, H, I, L, O, P$ & 106 & $\mathrm{~B}, \mathrm{C}, \mathrm{D}, \mathrm{G}, \mathrm{H}, \mathrm{I}, \mathrm{L}, \mathrm{O}, \mathrm{Q}$ \\
\hline 26 & $\mathrm{~A}, \mathrm{C}, \mathrm{E}, \mathrm{G}, \mathrm{H}, \mathrm{I}, \mathrm{L}, \mathrm{O}, \mathrm{P}$ & 53 & & 80 & $\mathrm{~B}, \mathrm{C}, \mathrm{E}, \mathrm{G}, \mathrm{H}, \mathrm{I}, \mathrm{L}, \mathrm{O}, \mathrm{P}$ & 107 & $\mathrm{~B}, \mathrm{C}, \mathrm{E}, \mathrm{G}, \mathrm{H}, \mathrm{I}, \mathrm{L}, \mathrm{O}, \mathrm{Q}$ \\
\hline 27 & & 54 & & 81 & & 108 & $\mathrm{~B}, \mathrm{C}, \mathrm{F}, \mathrm{G}, \mathrm{H}, \mathrm{I}, \mathrm{L}, \mathrm{O}, \mathrm{Q}$ \\
\hline
\end{tabular}

Index jensen's $(\alpha)$ model CAPM dan model APT:-

Calculating Jensen's portfolio index by using the following formula:

$$
\alpha=\mathrm{Rp}-\mathrm{E}(\mathrm{R})
$$

After E (Rp) of each combination is obtained then the value of the portfolio Jensen'n index $(\alpha)$ of the model CAPM and APT model can be calculated by using the formula above the monthly period so that we will get the value of $\alpha$ portfolio of 108 combinations. Then $\alpha$ portfolio value each combination calculated the mean (average) of its $\alpha$, so that there is only one (1) $\alpha$ within 1 (one) combined portfolio, and as a result there will be as many as $108108 \alpha$ on the combined portfolio. To determine the return combinations where the most optimal portfolio can be seen from an index value of Jensen's $(\alpha)$ of each of the combined portfolio, the greater the value of $\alpha$, the greater the return portfolio. Jensen's Index $(\alpha)$ the top 10 of the 108 combined portfolio CAPM and APT models shown in the following table.

Table 3:- Jensen's Index $(\alpha)$ top 10 CAPM model.

\begin{tabular}{|c|c|c|c|}
\hline No & Code & Combination & Indeks Jensen's $(\alpha)$ \\
\hline 1 & 77 & B, C, E, G, H, I, K, O, P & 0.025107 \\
\hline 2 & 80 & B, C, E, G, H, I, L, O, P & 0.024153 \\
\hline 3 & 104 & B, C, E, G, H, I, K, O, Q & 0.023378 \\
\hline 4 & 76 & B, C, D, G, H, I, K, O, P & 0.023085 \\
\hline 5 & 107 & B, C, E, G, H, I, L, O, Q & 0.022453 \\
\hline 6 & 79 & B, C, D, G, H, I, L, O, P & 0.022161 \\
\hline 7 & 68 & B, C, E, G, H, I, K, N, P & 0.021502 \\
\hline 8 & 103 & B, C, D, G, H, I, K, O, Q & 0.021385 \\
\hline 9 & 74 & B, C, E, G, H, I, J, O, P & 0.021249 \\
\hline 10 & 78 & B, C, F, G, H, I, K, O, P & 0.021093 \\
\hline
\end{tabular}


Table 4:- Jensen's Index $(\alpha)$ top 10 models of APT

\begin{tabular}{|c|c|c|c|}
\hline No & Code & Combination & Indeks Jensen's $(\alpha)$ \\
\hline 1 & 80 & B, C, E, G, H, I, L, O, P & 1.208032 \\
\hline 2 & 25 & A, C, D, G, H, I, L, O, P & 1.207309 \\
\hline 3 & 85 & B, C, D, G, H, I, K, M, Q & 1.190167 \\
\hline 4 & 26 & A, C, E, G, H, I, L, O, P & 1.140713 \\
\hline 5 & 100 & B, C, D, G, H, I, J, O, Q & 1.139271 \\
\hline 6 & 54 & A, C, F, G, H, I, L, O, Q & 1.131452 \\
\hline 7 & 55 & B, C, D, G, H, I, J, M, P & 1.112528 \\
\hline 8 & 105 & B, C, F, G, H, I, K, O, Q & 1.090122 \\
\hline 9 & 46 & A, C, D, G, H, I, J, O, Q & 1.071981 \\
\hline 10 & 101 & B, C, E, G, H, I, J, O, Q & 1.070365 \\
\hline
\end{tabular}

From Table 3 and Table 4 illustrates Alpha $(\alpha)$ is showing the difference between the actual investment returns with the expected investment returns or the benchmark for the level of market risk (beta) specific. On top ranking calculation results showed that the alpha value of 0.025107 CAPM model, which is a positive alpha value and meaning describe portfolio performance is good or feasible to do investment. While the alpha value of 1.208032 top APT model, demonstrating the value of alpha is positive and that means investment or portfolio performance in good standing and eligible to do investment.

\section{Different test by using T-Test Paired Samples Test:-}

To find out if there is a difference between Jensen's Index APT model with CAPM model used Jensen's t test. Based on calculations using the T-Test Paired Samples Test (Output Program SPSS Version 17:00) as set forth in the following table:

Table 5:- Data Test Result Differences Index of Jensen's t APT model with Jensen's Index CAPM model.

\begin{tabular}{|c|c|c|c|c|c|c|}
\hline & & \multicolumn{5}{|c|}{ Paired Differences } \\
\hline & & \multirow[t]{2}{*}{ Mean } & \multirow[t]{2}{*}{ Std. Deviation } & \multirow[t]{2}{*}{ Std. Error Mean } & \multicolumn{2}{|c|}{$\begin{array}{l}\text { 95\% Confidence Interval of the } \\
\text { Difference }\end{array}$} \\
\hline & & & & & Lower & Upper \\
\hline $\begin{array}{l}\text { Pair } \\
1\end{array}$ & $\begin{array}{l}\text { Jensen_APT - } \\
\text { Jensen_CAPM }\end{array}$ & .531223 & .374122 & .035999 & .459857 & .602589 \\
\hline
\end{tabular}

The data indicate that Jensen's Index APT model was higher than Jensen's Index CAPM model with a number of differences in the average standard deviation of 0.53223 to 0.374123 . Total average score of Jensen's Index APT model is 0.542808 , while the total score of the average Index of Jensen's model of CAMP is 0.011585 .

\section{Conclussion:-}

Based on the results of the discussion can be drawn conclusions as follows:-

1. The combination of the company that produces the optimal portfolio by using the CAPM model is PP London Sumatra Tbk, LIPPOKarawaciTbk, Indo TambangrayaTbk, Holcim Indonesia Tbk, PT Astra International Tbk, United Tractors Tbk, Bank MandiriTbk, Kalbe FarmaTbk and JasaMargaTbk, with an Index score of Jensen's CAPM model by 0.025107 .

2. The combination of the company that produces the optimal portfolio by using the APT model is PP London Sumatra Tbk, LippoKarawaciTbk, Indo TambangrayaTbk, Holcim Indonesia Tbk, PT Astra International Tbk, United Tractors Tbk, Bank of the Republic of Indonesia Tbk, Kalbe FarmaTbk and JasaMargaTbk, with an Index score of Jensen's APT model by 1.208032 .

3. The results of this study showed no significant difference between Jensen's index CAPM model with Jensen's index APT model, where Jensen's index APT model was higher than Jensen's Index CAPM model with a number of differences in the average standard deviation of 0.53223 to 0.374123 . Total average score of Jensen's index APT model is 0.542808, while the average score of Jensen's index CAPM model is 0.011585 . 


\section{References:-}

1. ArzacdanBawa, "Portfolio Choice and Equilibrium in Capital Markets with Safety-First Investors". Journal of Economics 4 (1977) 277-288, North- Holland Publishing Company, 1977.

2. ArifinZaenal, Theory of Financial and Capital Markets, Ekonisia,Yogyakarta 2007.

3. AdhiDarmawanSutjiadi, "Application Network Trees Under Tree Diagram ", Journal of Computer Science and Information Technology, 2003.

4. AgusSumanto, "The validity of the use of CAPM in Predicting Stock Return on the JSE ", Journal of Accounting and Finance, 2005.

5. ArduinoCagnetti, "Comparison Model CAPM with APT", Journal of Accounting and Finance, 2002.

6. Black dan Scholes, "International Capital Market Equilibrium with Investment Barriers". Journal of Financial Economis 1 (1974) 337-352 North-Holland Publishing Company, 1974.

7. Bloomfield, et.al, "Portfolio Strategies and Performance".Journal of Financial Economics 5 (1977) 201-218, North-Holland Publishing Company, 1977

8. Brealey, Richard A. Stewart C, Myers. Alan J, Marcus, Fundamental of Corporate Finance, Third Edition, Singapore, McGraw-Hill, 2001.

9. Cornell, “ Asymmetric Information and Portfolio Performance Measurement”. Journal of Financial Economics 7 (1979) 381-390, North-Holland Publishing Company, 1979.

10. DoddySetiawan, Analysis of Factors Affecting Fundamental Systematic Risk Before and During the Monetary Crisis, National Symposium Papers Accounting VI, Surabaya:565-573, 2003.

11. DermawanSjahrial, Financial management, MitraWacana Media, Jakarta, 2010.

12. GancarCandraPremanantodanMuhamadMadyan, "Comparison of Accuracy in Predicting CAPM with APT Income Level Manufacturing Industry Before and During Economic Crisis", Journal of Finance, 2003.

13. GudonodanNinikNurhayati, The Association between Market Determined and Accounting Determined Risk Measure: Evidence from Indonesia, Journal of Accounting Research, Management and Economics 1, Agustus: 171-176, 2001.

14. Gujarati, Damodar, Basic Econometrics, International Edition, Mc-Graw Hill, 2003.

15. Halim Abdul, Investment analysis, SalembaEmpat, Jakarta, 2005.

16. HusnanSuad, Basics of Portfolio Theory and Analysis Securities, Publishing and Printing Unit AMP YKPN, Yogyakarta, 2005.

17. Hidayat, Ichsan, Syamsudin, "The use of Multi Index Estimation Model in Return on Investment Shares in Indonesia", Journal of Accounting and Finance, 2004.

18. Keown, Arthur J. Martin, John D. PettiJ. William Scott Jr., David F, Financial Management Principles and Applications, Ninth Edition, New Jersey, Prentice Hall, 2002.

19. Krishnan, G., danGul, F. A., "Has Audit Quality Declined? Evidence From the Pricing of Discretionary Accruals", Working Paper, 2002.

20. Krishnan, G., "Audit Quality and The Pricing of Discretionary Accruals", Working Papers, 2002.

21. Mayo, Herbert B, Financial Institution Investments and Management, Seventh Edition, New York, Harcourt College Publishers, 2001.

22. MichellSuharli, "Empirical Study Of Two Factors Affecting the Stock Return on Food \& Beverages Industry in BEI", Journal of Accounting and Finance, 2005.

23. M. Jogiyanto Hartono, Portfolio Theory and Investment Analysis, BPFE, Yogyakarta, 2003.

24. RetnoWidyaSasantidanNurfauziah, "Factors Implications of the Shares on the JSE Price Fluctuation", Journal of Accounting and Finance, 2001.

25. SamsulMohamad, Capital Markets and Portfolio Management, Erlangga, Jakarta 2006.

26. Sugiyono, Business Research Methods, CV. Alfabeta, Bandung, 2009.

27. WidoatmodjoSawidji, Stock investment, PT. Elex Media Komputindo, Jakarta, 2008.

28. WidoatmodjoSawidji, Cara Healthy Investment in Capital Market, PT. Elex Media Komputindo, Jakarta, 2008.

29. ZubirZalmi, The Application Portfolio Management Investment In Stocks, SalembaEmpat, Jakarta, 2011. 